\title{
Effect of method of measuring on size of electrostatic charge and grinding efficiency of a pinewood
}

\author{
Wpływ metody pomiaru na wielkość ładunków elektrostatycznych \\ w czasie szlifowania drewna sosnowego
}

\section{STANISŁAW PŁONKA PIOTR ZYZAK *}

\begin{abstract}
In the paper is presented a station to measurement of electrostatic charge generated during grinding operation of pinewood. Size of the charge was determined in course of measurement of voltage in function of time. It has been investigated an effect of two types of abrasive papers: general-purpose paper of PS 18E brand and antistatic one of PS $15 \mathrm{~F}$ brand on value of the voltage during grinding operation, and weight efficiency of a specimens made from the pinewood, at constant pressure equal to $p=4,54 \mathrm{kPa}$ and variable grinding speed $v_{\mathrm{c}}$ in range from 12,1 to $24,2 \mathrm{~m} / \mathrm{s}$. It was found that the method of measuring electrostatic charges by recording voltage in the time function $U=f(t)$ has a significant effect primarily on the sign of arising charges and the repeatability of the obtained voltage waveforms during grinding.
\end{abstract}

KEYWORDS: grinding, abrasive papers, methods of measuring electrostatic charges

In industrial practice, abrasive machining processes can be carried out using various types of abrasive tools. Depending on their type, two basic groups of abrasive machining are distinguished: bonded abrasive and loose abrasive. Abrasive grinding includes: grinding with grinding wheels, smoothing, oscillating super-smoothing and belt grinding, i.e. grinding with papers and abrasive cloths $[1,3$, $6,7,9]$.

Perspective methods of abrasive machining include machining with abrasive tools on flexible substrates, and above all machining with abrasive papers and abrasive strips and disc blades. Among the methods of finishing and surface finishing of wood, grinding with abrasive tools is of particular importance - almost $100 \%$ of operations are performed with these tools. Such grinding serves both to eliminate errors of shape and dimensions, as well as to improve the quality of the surface or prepare it for further production stages, e.g. veneering, varnishing or printing [9].

\footnotetext{
* Prof. dr hab. inż. Stanisław Płonka (splonka@ath.bielsko.pl), dr inż. Piotr Zyzak (pzyzak@ath.bielsko.pl) - Akademia Techniczno-Humanistyczna w Bielsku-Białej
}

The striving to increase the efficiency of machining and improve the quality of the workpieces resulted in the development and manufacture of new varieties of coated abrasive tools, including anti-static cloths and papers [5, $8-10,12]$. These tools allow to reduce, or even almost eliminate, the phenomenon of electrostatic charges on the surface of active canvas and abrasive papers - PCPS [4].

This article is a continuation of the research discussed in [8], and its aim is to evaluate the method of measuring the size of electrostatic charges generated during grinding pine wood with abrasive papers (ordinary and antistatic), in terms of the sign and repeatability of the obtained voltage waveforms.

\section{Methodology for measuring electrostatic charges}

Grinding is accompanied by friction and elevated temperature, which promotes the formation of electrostatic charges. If these charges are not discharged through the ground, then there is an electrostatic charge of the PCPS, as well as the ground object and the fine chips of the material being processed. The effect of this charge is the magnetic adhesion of dust to the workpiece, sandpaper and machine tool $[2,11]$. Due to the use of antistatic abrasive papers, which in the composition of the primer or binder layer contain special binding agents in the form of carbon fibers, graphite and soot, the generated electrostatic charges can be removed.

Studies on the process of electrostatic charge formation during grinding of pine wood samples with abrasive papers were carried out on a special stand built on the basis of the NUA-25 grinder (fig. 1).

Various constructional solutions were used to capture electrostatic charges generated on PCPS: a graphite-copper brush (element 10 in fig. 1) and a flat copper plate (item 4 in fig. 2), spaced from the active surface of the abrasive paper by $1 \mathrm{~mm}$. Cargo values were at a similar level, while differences in the sign of generated electrostatic charges were observed.

Standard PS 18E abrasive papers and anti-static PS 15F by KLINGSPOR had the form of discs with dimensions $\varnothing 140 \times \varnothing 35 \mathrm{~mm}$. The properties of sanding papers are shown in the table. 


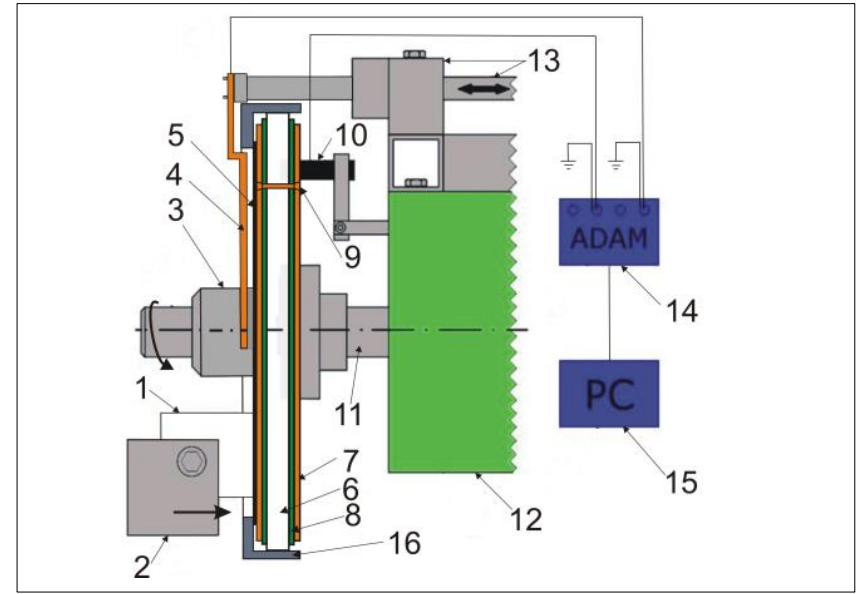

Fig. 1. Electrostatic charge measurement stand: 1 - wood sample, 2 - sample mounting, 3 - nut, 4 - copper element for capturing loads in front of sandpaper, 5 - sanding disk, 6 - paper clamping plate, 7 - conductive copper cladding, 8 - insulating layer, 9 - copper peg (electrical connection), 10 - graphite copper brushes, 11 - grinding and sharpening spindle, 12 - grinding and sharpening body, 13 - element guide system for interception of cargo, 14 - ADAM 4118 measurement module, 15-PC computer, 16 - paper clamping disc

TABLE. Characteristics of abrasive papers used in research [8]

\begin{tabular}{|c|c|}
\hline Symbol & Characteristics and form \\
\hline \multirow{2}{*}{ PS 18E 120} & $\begin{array}{l}\text { Specialized product for machine grinding of soft } \\
\text { wood with a high resin content on the substrate } \\
\mathrm{E} \text {, binder and adhesive: resin, grain: fine alumina } \\
\text { 99A, open embankment }\end{array}$ \\
\hline & $\begin{array}{l}\text { Abrasive disc, outer diameter } 140 \mathrm{~mm} \text {, } \\
\text { hole diameter } 35 \mathrm{~mm} \text {, number of pieces } 100\end{array}$ \\
\hline \multirow[t]{2}{*}{ PS 15F 120} & $\begin{array}{l}\text { Highly efficient, specialized product with } \\
\text { antistatic properties for machine grinding of } \\
\text { highly resins soft wood, on the F substrate, } \\
\text { underlay and primer adhesive: resin with the } \\
\text { addition of } 5 \% \text { soot, grain: noble electro- } \\
\text { corundum 99A, open embankment }\end{array}$ \\
\hline & $\begin{array}{l}\text { Abrasive disc, outer diameter } 140 \mathrm{~mm} \text {, } \\
\text { hole diameter } 35 \mathrm{~mm} \text {, number of pieces } 100\end{array}$ \\
\hline
\end{tabular}

The ordinary and antistatic abrasive paper discs were subjected to resistance tests - both on the side of the embankment and on the substrate [2.11] - using the $\mathrm{CHY}$ $\mathrm{M}-1000 \mathrm{~V}$ mega-ohmometer. The resistance of antistatic abrasive paper from the embankment side was $100 \div 200$ $\mathrm{M} \Omega$, and on the substrate side $-20 \div 30 \mathrm{M} \Omega$. In the case of ordinary abrasive paper, the resistance from the side of the embankment and from the surface of the substrate exceeded 2,000 $\mathrm{M} \Omega$.

200 pine samples $30 \times 30 \times 72 \mathrm{~mm}$ were prepared for the needs of the research. Each sample was subjected to three measurements of wood moisture using a VOLTCRAFT FM-300 moisture meter with automatic temperature compensation. Then, the arithmetic mean of the measurements was calculated and the samples were selected. The grinding operation was carried out on those samples, the moisture content of which was in the range of $7.5 \div 8.5 \%$.

The amount of electrostatic charges was determined by measuring the value of voltage (potential difference) as a function of time $U=f(t)$ when grinding samples with normal and antistatic abrasive paper, with constant surface pressure $p=4.54 \mathrm{kPa}$ and variable grinding speed $v_{\mathrm{c}}$ from the range of 12,1 to $24.2 \mathrm{~m} / \mathrm{s}$. The value of generated voltage as a function of time was recorded on the computer monitor in the form of graphs $U=f(t)$.

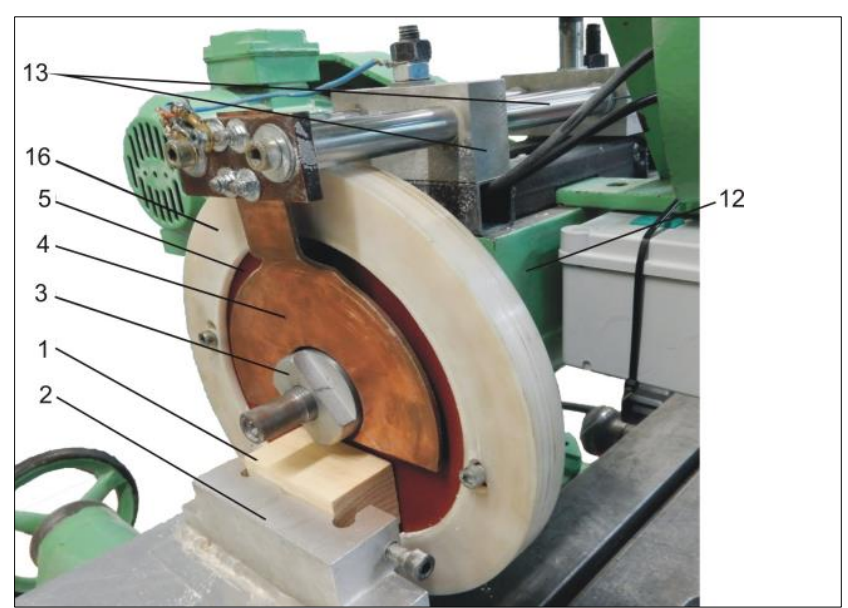

Fig. 2. Electrostatic charge measurement using appropriately shaped copper sheet: 1 - wood sample, 2 - sample mounting, 3 - nut, 4 - copper element for capturing loads in front of sandpaper, 5 - sanding disk, 12 - the body of the grinding and sharpening machine, 13 - the guide system of the element for the interception of cargo, 16 - the shield for fixing the paper

The measuring module from the ADAM 4118 series was used to acquire measurement data during the tests. It enables the recording and visualization of analog signal waveforms as a function of time and communication with a PC computer using the RS 485 bus. The intermediary element is a microprocessor converter ATC 820 installed in Windows as a port serial COM. The ADAM 4118 measuring module allows temperature measurement from $-50{ }^{\circ} \mathrm{C}$ to $1300{ }^{\circ} \mathrm{C}$ and voltage measurement (potential difference). The discretization step was programmed for $0.1 \mathrm{~s}$.

\section{Results of measurements of electrostatic charges}

Measurement of electrostatic charges using a graphitecopper brush showed that in most cases (about 75\%) when grinding pine specimens with ordinary PS $18 \mathrm{E}$ abrasive papers, the voltage values in the time interval from 0.5 to $20 \mathrm{~s}$ are positive. The maximum voltage values usually occur after $1 \div 1.5 \mathrm{~s}$ from the beginning of grinding and are generally from $U=0.9 \mathrm{mV}$ to $U=1.9 \mathrm{mV}$. Then the voltage drops sharply to around $U=0.5 \mathrm{mV}$, and even $U=0.2 \mathrm{mV}$.

On the other hand, when grinding pine wood with antistatic PS $15 \mathrm{~F}$ abrasives, the voltage values in the time interval from 1.5 to $20 \mathrm{~s}$ are negative. After about 2 seconds the voltage values usually oscillate from the smallest value $U=-0.2 \mathrm{mV}$ to the value close to zero. The highest voltage values - from $U=-0.6 \mathrm{mV}$ to $U=-0.1 \mathrm{mV}$ - usually occur after $1 \div 2 \mathrm{~s}$.

Sample graphs of voltage as a function of time $U=f(t)-$ measured using a graphite-copper brush on the surface of ordinary and antistatic abrasive paper while grinding samples is shown in fig. 3. As can be seen, voltage waveforms shown in fig. $3 \mathrm{~b}$ are more stable.

On the basis of the measurement of electrostatic charges with the use of copper sheet from the side of the abrasive paper coating, it was found that in $55 \%$ of cases when grinding pine wood samples with PS $18 \mathrm{E}$ abrasive papers, the voltage values in the time interval from 0.5 to $20 \mathrm{~s}$ are negative. The highest voltage values - from $U=-1.12 \mathrm{mV}$ to $U=-0.8 \mathrm{mV}$ - generally occur in the time interval $0.8 \div 1.5$ s. After approx. $3 \div 4 \mathrm{~s}$, voltage stabilization usually occurs in the interval values from $U=-0.6$ to $U=-0.4 \mathrm{mV}$. When grinding samples with antistatic PS $15 \mathrm{~F}$ abrasives, the voltage in the tested time interval is almost always positive and reaches values from zero to approx. $0.45 \mathrm{mV}$. The highest voltage values - from $U=0.15 \mathrm{mV}$ to $U=0.45 \mathrm{mV}-$ usually occur in the time interval from 0.8 to approx. $2 \mathrm{~s}$. After approx. 2 to $4 \mathrm{~s}$, the voltage stabilizes - usually at the level from 0.1 to $0.2 \mathrm{mV}$. 


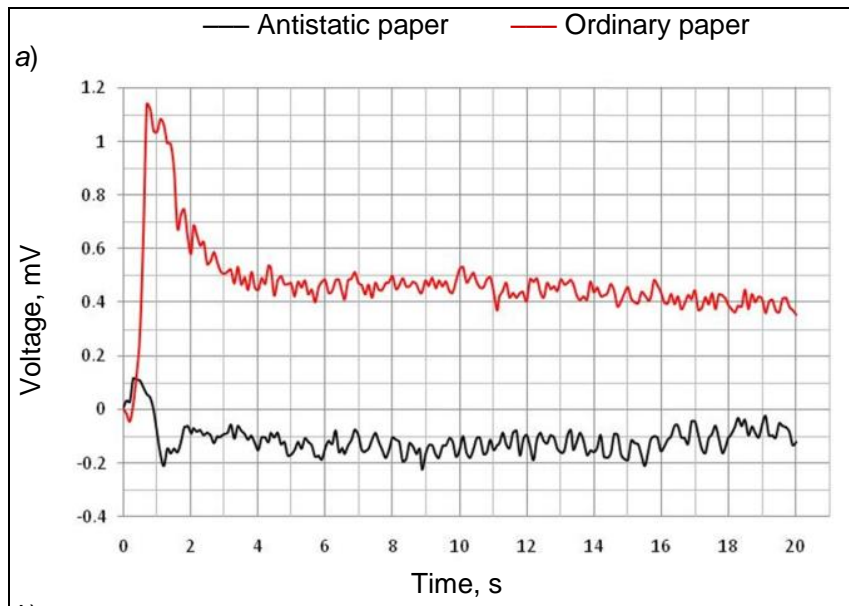

b)

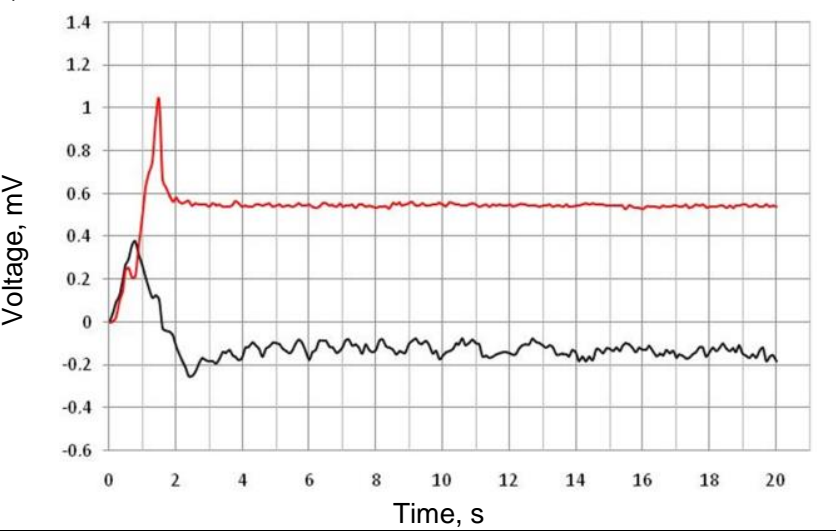

Fig. 3. Time waveforms of the voltage generated on the surface of ordinary and antistatic abrasive paper when grinding a sample of pine wood, obtained using a graphite-copper brush: a) a less stable course, $b$ ) a stable course

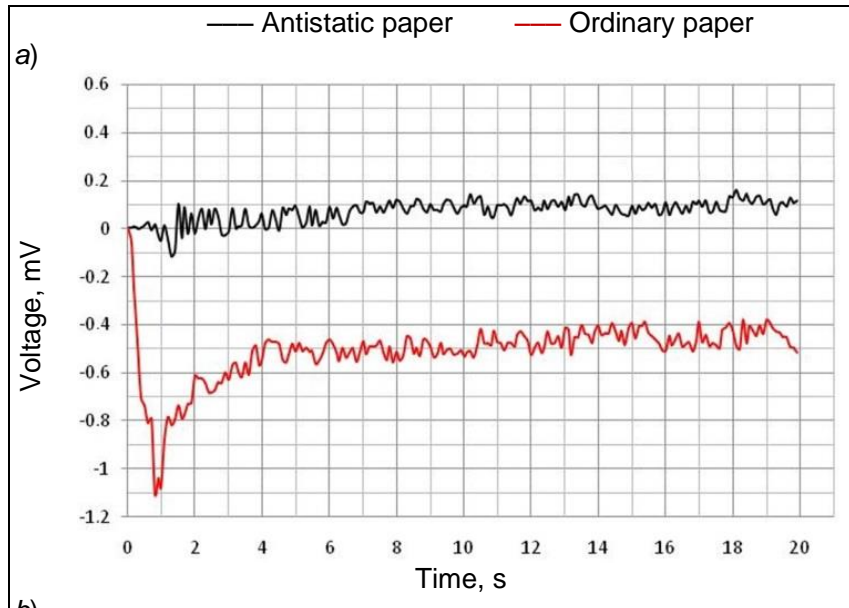

b)

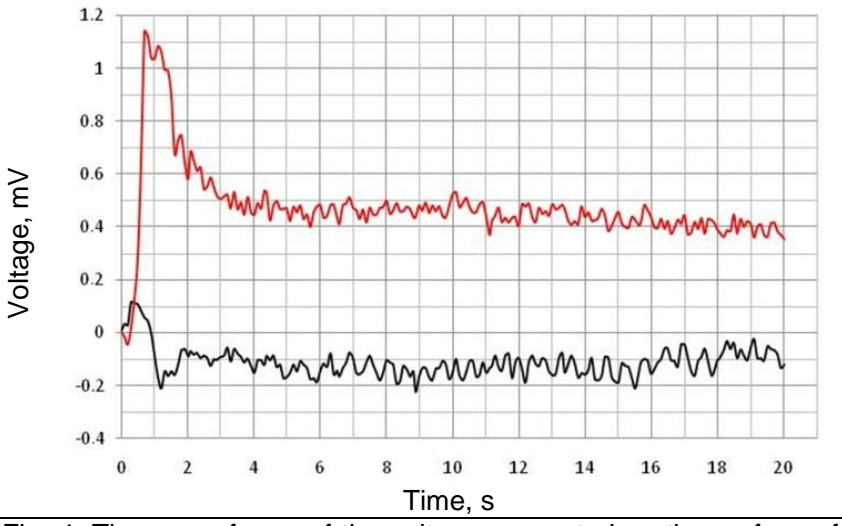

Fig. 4. Time waveforms of the voltage generated on the surface of ordinary and antistatic abrasive paper when grinding a sample of pine wood, obtained using copper sheet: a) less stable course, b) stable course
Sample graphs of voltage as a function of time $U=f(t)$ - measured using copper sheet - on the surface of ordinary and antistatic abrasive paper during grinding of samples are shown in fig. 4 . The waveforms shown in fig. $4 b$ are more stable.

The $U=f(t)$ diagrams removed using copper sheet are markedly less repeatable voltage values (electrostatic charges) in relation to the voltage measured using a graphite-copper brush. It can therefore be concluded that the voltage values removed by means of copper sheet are less stable and more susceptible to various types of interference. That is why in further research it was decided to use a graphite-copper brush for measuring tension.

\section{Evaluation of the degree of covering of abrasive papers}

The phenomenon of electrostatic charge generation is very undesirable because it results in a much faster adhering of the space between the grains of the active surface of abrasive paper with wood particles. PCPS surfacing is compounded as a result of the formation of unlike charges of grinding dust. Attempts to assess the degree of PCPS overfilling by measuring - in the same ambient conditions - the weight of the paper envelope, and then the weight of the envelope together with the sanding disk prior to grinding and after sanding the wood sample as well as the SEM image analysis method [8, 10], did not give any definite results. This can be explained, among others in that after removing the wood sample from the PCPS, i.e. after the abandonment of the grinding operation, the electrostatic charges cease to be generated immediately, and the previously generated charges are discharged into the machine body. As a result, some particles of wood and dust fall away from PCPS immediately. Only when grinding wood samples with a certain amount of resin using antistatic abrasive paper, one can notice a significant weakening of this phenomenon.

Photographs of the active surface of abrasive paper PS $18 \mathrm{E}$ before the grinding operation and after grinding the pine wood sample for approx. $30 \mathrm{~s}$ are shown in fig. 5. Fig. 6 shows the pictures of the active surface of antistatic PS $15 \mathrm{~F}$ paper before and after the grinding operation. As can be seen, the staining of the active surface of ordinary abrasive paper - resin and fine particles of wood - is much more intense compared to antistatic abrasive paper, despite the same grinding conditions (i.e. surface pressure and peripheral speed)

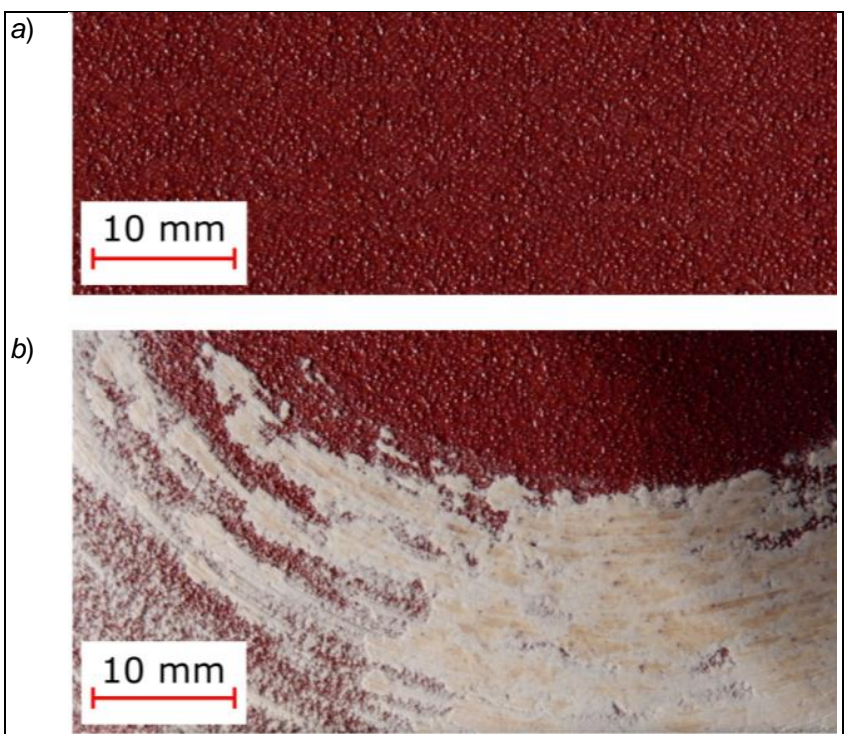

Fig. 5. Active surface of abrasive paper PS 18E 120: a) before grinding, $b$ ) after sanding pine wood with parameters $p=4.54 \mathrm{kPa}$ and $v_{c}=12.1 \div 24.2 \mathrm{~m} / \mathrm{s}$ (visible coverage of the active surface resin and wood particles) 


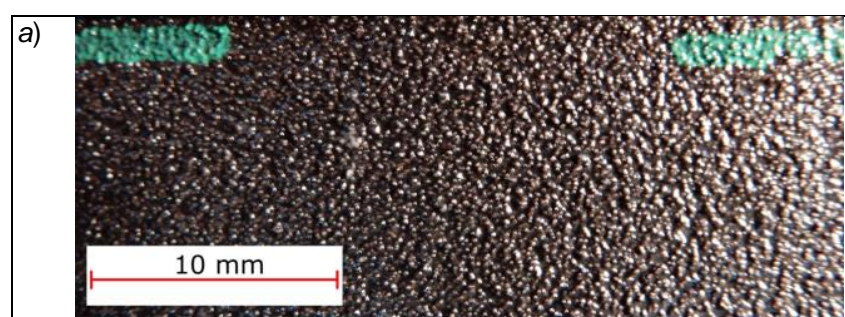

b)

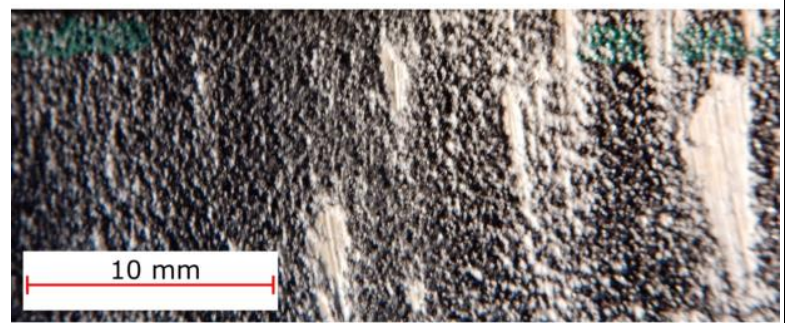

Fig. 6. Active surface of antistatic abrasive paper PS 15F 120: a) before grinding, $b$ ) after sanding pine wood with parameters $p=4.54 \mathrm{kPa}$ and $v_{\mathrm{c}}=12.1 \div 24.2 \mathrm{~m} / \mathrm{s}$ (visible coverage of the active surface resin and wood particles)

This should be explained by the fact that the value of generated voltage (and thus electrostatic charges) when grinding pine wood samples with ordinary abrasive paper is about $4 \div 6$ times higher than during the grinding process using antistatic abrasive paper. Also, the resistance of ordinary abrasive paper from the substrate side is from about 67 to over 200 times the resistance of antistatic abrasive paper, which significantly hinders discharge of electrostatic charges to the grinding body. Consequently, the spaces between the grains of ordinary abrasive paper remain more filled with particles of wood, dust and resin.

\section{Conclusions}

On the basis of conducted research on grinding pine wood with abrasive papers - ordinary PS $18 \mathrm{E}$ and antistatic PS $15 \mathrm{~F}$ - it was found that:

- the method of measuring electrostatic charges by recording voltage as a function of time $U=f(t)$ has a significant impact primarily on the sign of arising charges and repeatability of voltage waveforms during grinding;

- method of measuring electrostatic charges with a graphite-copper brush gives a much better repeatability of voltage waveforms during grinding;

- the value of the generated maximum voltage when grinding wood with ordinary abrasives is usually several times higher than the voltage generated during grinding with anti-static abrasive papers, and the resulting electrostatic charges are of opposite signs;

- resistance of antistatic abrasive papers from the side of the embankment is at least a dozen, and from the side of the substrate - several dozen times smaller in relation to the resistance of ordinary abrasive papers.

Significantly less intensive application of the active surface of abrasive paper with resin and wood particles during grinding with antistatic abrasives should be explained by generating electrostatic charges of the opposite sign and several times smaller, as well as many times less paper resistance (both on the side of the embankment and the ground) discharged to the body of the grinder in a much shorter time.

\section{REFERENCES}

1. Feld M., Szpunar A. „Szlifowanie materiałów konstrukcyjnych taśmami ściernymi”. Warszawa: Wydawnictwa NaukowoTechniczne, 1977.

2. Gajewski A. "Procesy i technologie elektrostatyczne”. Warszawa: PWN, 2000.
3. Kaczmarek J. „Podstawy obróbki wiórowej, ściernej i erozyjnej". Warszawa: Wydawnictwa Naukowo-Techniczne, 1970.

4. Koziarski A. „Czynna powierzchnia ściernicy. Metody badań makro- i mikrogeometrii". Monografie. Politechnika Łódzka, 1996.

5. Materiały informacyjne firmy KLINGSPOR.

6. Oczoś K.E. „Szlifowanie taśmą ścierną materiałów metalowych i niemetalowych". Mechanik. 65, 10 (1992).

7. Oczoś K.E., Porzycki J. "Szlifowanie. Podstawy i technika”. Warszawa: Wydawnictwa Naukowo-Techniczne, 1986.

8. Płonka S., Zyzak P. „Wpływ rodzaju papieru ściernego na wielkość ładunków elektrostatycznych i wydajność szlifowania drewna sosnowego". Mechanik. 89, 8-9 (2016): pp. 1072-1073.

9. Pszczołowski W., Rosienkiewicz P. „Obróbka ścierna narzędziami nasypowymi”. Warszawa: Wydawnictwa Naukowo-Techniczne, 1995.

10. Szadkowski J., Płonka S., Kula K., Morończyk A. „Wpływ ładunków elektrostatycznych na szlifowanie drewna narzędziami nasypowymi". Zbiór prac VI Konferencji NaukowoTechnicznej „Kształtowanie Materiałów Niemetalowych", Zakopane: 2001.

11. PN-92/E-05203 Ochrona przed elektrycznością statyczną. Materiały i wyroby stosowane $\mathrm{w}$ obiektach oraz strefach zagrożonych wybuchem. Metody badań oporu właściwego oraz upływu.

12. www.abrasives.pl (12.03.2018).

Translation of scientific articles, their computer composition and publishing them on the website www.mechanik.media.pl by original articles in Polish is a task financed from the funds of the Ministry of Science and Higher Education designated for dissemination of science.

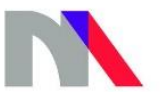

Ministry of Science and Higher Education

Republic of Poland 